\title{
PULSING WITH SUCROSE AND SILVER NITRATE ENHANCE WATER UPTAKE AND RESULT IN ALONG VASE LIFE IN TAIF ROSE CUT FLOWERS (Rosa damascena. CV. TRIGINTIPETALA)
}

\author{
ELGIMABI M.N.E.E.* \\ Department of Biology, Taif University, Saudi Arabia. \\ *Corresponding Author: Email- nourde1@yahoo.com
}

Received: February 10, 2014; Accepted: March 27, 2014

\begin{abstract}
An experiment was carried out on Taif rose cut flowers cv. (Trigintipetala) to study the effect of pulsing with sucrose and silver nitrate $\left(\mathrm{AgNO}_{3}\right)$ on vase life and other parameters. In the trial, sucrose and $\mathrm{AgNO}_{3}$ at 4 levels of concentrations $(0,3,5$ or $7 \% \mathrm{w} / \mathrm{v}$ sucrose), $(0$, 20,30 or $50 \mathrm{ppm} \mathrm{AgNO}_{3}$ ) were tested alone as well as combination. The cut flowers were treated in three stages of maturity [bud (B), half opening (H.O) or complete opening (C.O)]. The pulsing times were 5, 10 or 24 hours, then transferred to distilled water as control. The experiment was laid out in a completely randomized design replicated thrice. The sucrose, $7 \%$ and $\mathrm{AgNO}_{3} 30 \%$ individually recorded higher vase life of 17.2 and 15 days respectively. Whereas, their combinations (sucrose $7 \% \times \mathrm{AgNO}_{3} 30 \%$ ) was significantly superior to the rest of combination in keeping higher water uptake and retarded the chlorophyll as well as the carbohydrate degradation during the postharvest life and resulting in a highest vase life of 19.1 days.
\end{abstract}

Keywords- Longevity, Taif rose cut flowers, $\mathrm{AgNO}_{3}$, Sucrose, water uptake, Chlorophyll, carbohydrate

Citation: Elgimabi M.N.E.E. (2014) Pulsing with sucrose and silver nitrate enhance water uptake and result in along vase life in Taif Rose cut flowers (Rosa damascena. cv. Trigintipetala). International Journal of Agriculture Sciences, ISSN: 0975-3710 \& E-ISSN: 0975-9107, Volume 6, Issue 1, pp.-379-383.

Copyright: Copyright@2014 Elgimabi M.N.E.E. This is an open-access article distributed under the terms of the Creative Commons Attribution License, which permits unrestricted use, distribution and reproduction in any medium, provided the original author and source are credited.

\section{Introduction}

Rose is one of the most popular cut flowers in different countries for highest economic importance in the floricultural industry [1], and a very long vase life compared to other cut flowers [2], which is one of the characteristics demanding in a commercial value of the ornamental flowers. Taif rose have an important role in the national economy for its great value in exportation of its oil to the Arab countries, ornamentation, medicinal use as well as manufacture of perfumes, [3]. Vase life termination for many cut flowers is characterized by wilting [4]. Water balance is a major factor determining quality and longevity of cut flowers. It is influenced by water uptake and transpiration and balance between two mentioned processes [5]. When the amount of transpiration exceeds the volume of water uptake, water deficit and wilting develops [6]. Low water uptake is often due to occlusions located mainly in the basal stem end [4]. Microorganisms are communally cause of stem blockage of xylem vessels which accumulated in the vase solution or in the vessels [7] and result a negative effect on the continuing water uptake and transportation by the leaves of cut flowers and stem tissue [8,9], and finally shortening there vase life $[10,11]$, and reduces water uptake. This blockage of xylem vessels led to water stress, which was expressed in the form of early wilting of leaves or flowers [7]. Pulsing with high concentration of silver nitrate is beneficial in extending the life of many cut flowers like gerberas, gladioli, chrysanthemum carnation and roses $[12,13]$. Tight carnation buds were opened in 10\% sucrose after impregnating the stems for 1 hour in a $1000 \mathrm{ppm} \mathrm{AgNO}_{3}$ solution [12]. Pulsing of cut roses for 10 and 20 min with $\mathrm{AgNO}_{3}$ improved the vase life up to 6.0 and 5.3 days, respectively [14]. Application of $\mathrm{AgNO}_{3}$ significantly increased the vase life as well as the gain fresh weight of rose as compared to 5.3 days in control [15]. Also, sucrose acts as a preservative materials, in addition to extending the vase life of cut flowers [16]. Different concentrations of sucrose ranging from 0 to $7.5 \%$ had been investigated by Pun, et al. [17] on cut spray carnation, they found that 5.0 sucrose recorded the best vase life and delayed the climacteric ethylene in petals. Furthermore. Butt, 2005 [18] study the effect of sucrose in different concentrations on two cultivars of Rosa hybirida and results showed that sucrose at $25 \mathrm{gL}^{-1}$ extended the vase life by 8.2 days.

On the other hands, sugars with biocides have become an important preservatives for floral several cut flowers [19], and prevented bent-neck of flower stems of \{Cara Mia\} rose cultivar [20]. Butt, [21] reported that when cut roses were treated with sucrose for 16 hours, the treatment increased the soluble sugar content, and reduced both photosynthesis rate and chlorophyll content. However, it stimulated the respiration rate of leaves, as compared with the control [12]. Also Nair, et al [22] study the effect of $\left(\mathrm{Ag} \mathrm{NO}_{3}\right)$ plus sucrose in different concentration on vase life of gerbera cut flower, the treatment extended the vase life and delaying the head dropping and discoloration. 


\section{Material and Methods}

Experiment 1

\section{Plant Materials}

Cut flowers of Taif roses were used for different trials. The flowers were obtained directly from the commercial grower. The flowering stems were trimmed to a uniform length of $25 \mathrm{~cm}$ to flowers at different stages and for different pulsing time. Then a smooth slanting cut were made to flower stem to facilitate the optimum up take of given solutions. Cutting had been done underwater to avoid air embolisms. All leaves on the lower section of the stem were removed. The sample had been divided into 30 groups with five replications, each replication contain one flower (to avoid contamination). They were kept at room temperature $23 \pm 1^{\circ} \mathrm{C}$ at normal day light and natural ventilation. Flowers had been harvested in three stages" bud stage (B.S), one or two basal flowers open [half opening] (H.O.S), or when they are fully opened (C.O.S)".

\section{Treatment Setting}

Treatments were set following a completely randomized design. Each treatment represented by 5 replication.

\section{Chemical Preparation}

Chemicals were obtained from a trading company in Saudi Arabia. Analytically pure Silver nitrate $\left(\mathrm{AgNO}_{3}\right)$ had been pulsed as follow: 1st Trial: Five hours only for $\mathrm{AgNO}_{3}$ at concentrations of $30,50,70$ ppm. Then flowers were transferred into $250 \mathrm{ml}$ glass bottle filled with distilled water along the duration of experiment (for the three stages).

2nd Trial: Ten hours only for. $\mathrm{AgNO}_{3}$ at concentrations of 30,50 , $70 \mathrm{ppm}$. Then flowers were transferred into $250 \mathrm{ml}$ glass bottle filled with distilled water along the duration of experiment (for the three stages).

3rd Trial: Twenty four hours for $\mathrm{AgNO}_{3}$ at concentrations of 30,50, $70 \mathrm{ppm}$. Then flowers were transferred into $250 \mathrm{ml}$ glass bottle filled with distilled water along the duration of experiment (for the three stages).

Also analytically pure sucrose had been pulsed as fallow:

1st Trial: Five hours (5h) at concentration of $3 \%, 5 \%$ and $7 \%$. w/v. Then flowers were placed in $250 \mathrm{ml}$ glass bottle containing distilled water, along the duration of experiment (for the three stages).

2nd Trial: Ten hours (10h) at concentration of 3\%, 5\% and 7\%. w/ v. Then flowers were placed in $250 \mathrm{ml}$ glass bottle containing distilled water, along the duration of experiment (for the three stages).

3rd Trial: Twenty four hours (24h) at concentration of $3 \%, 5 \%$ and $7 \%$. w/v. Then flowers were placed in $250 \mathrm{ml}$ glass bottle containing distilled water, along the duration of experiment (for the three stages).

\section{Control Treatment}

Flowers was trimmed in different stages of maturity and kept in $250 \mathrm{ml}$ distilled water along the duration of the experiment, as a control treatment for the different trials.

\section{Vase Life Determination}

Visual rating of flowers was carried out on the basis of a scale from 1 to 4 when: 1 = entirely fresh flowers, 2 = initiation of wilting in $20 \%$ of petals and beginning of bent neck, $3=$ wilting in $20-50 \%$ of petals and increasing the bent neck, $4=$ wilting in $50-100 \%$ of petals.

\section{Experiment 2}

\section{Plant Material}

The same preparation of plant material mentioned in experiment (1)

\section{Chemical Treatments}

\section{$\left(\mathrm{AgNO}_{3}\right)+$ Sucrose Treatments}

Silver nitrate $\left(\mathrm{AgNO}_{3}\right.$ at $\left.30 \mathrm{ppm}\right)$ was applied for 24 hour depending on the previous results (which the best one), whether with or without sucrose at $7 \%(\mathrm{w} / \mathrm{v})$ the concentration, which attained the best results in the previous experiment. The two compounds are dissolved in sterilized distilled water in glass bottle containing $250 \mathrm{ml}$ to study the effect of their interaction.

\section{Control Treatment}

Flowers are trimmed and kept in $250 \mathrm{ml}$ distilled sterilized water along the duration of the experiment, as a control treatment for different experiments.

\section{Vase Life Determination}

Vase life of rose cut flowers was measured as mentioned in experiment (1)

\section{Fresh Weight Measurements}

Fresh weight determination of the flowers were mad just before the immersion of flowers into the solutions and repeated on the day when the vase life of the control flowers was terminated. The flowers are taken out of solutions after 24 hours pulsing time.

\section{Chlorophyll Determination}

Chlorophyll content was measured for the best treatment of each chemical for all cut flowers under study. Chlorophyll content of sepals segments was extracted by methanol and the absorbance was determine by spectrophotometer. This was done on day 0,5 , and on the day when the vase life of the control flowers are terminate. The samples were collected separately from each replicate and the average of the three replicates was calculate. The chlorophyll concentration was calculated as $\mathrm{mg} \mathrm{l}^{-1}$ fresh weight. The equations for the determination of concentrations of chl. $A$ and $\mathrm{chl} b$ were $\mathrm{Chl} a$ $\left(\mathrm{mg} \mathrm{l}^{-1}\right)=12.21 A_{663}-2.81 A_{646} \mathrm{Chl} b\left(\mathrm{mg} \mathrm{l}^{-1}\right)=20.13 A_{646}-5.03$ A663.

\section{Carbohydrate Determination}

Soluble carbohydrate determined on stem of the best treatment of each chemical and the best stage of maturity and best pulsing time, tested in the study. Sample were taken on the same day as mentioned in chlorophyll determination. One flowering stem from each replicate was used. Dried sample were ground together into homogenized powder, using a household crusher $(10 \mathrm{mg}$ of oven-dried plant material were extracted by $10 \mathrm{ml}$ of borate buffer $(28.63 \mathrm{~g}$ boric acid $+29.8 \mathrm{~g} \mathrm{KCL}+3.5 \mathrm{~g} \mathrm{NaOH}$ in IL of hot de-ionized distilled water), left overnight, and filtered. Using spectrophotometer to detect the different types of sucrose.

\section{Results and Discussion \\ Effect of $\mathrm{AgNO}_{3}$ and Sucrose on Vase Life of Taif Rose Cut Flowers}

Vase Life- The statistical analysis of results showed that the $\mathrm{AgNO}_{3}$ $\&$ sucrose, significantly extended the vase life of Taif rose cut flowers compared to control in different concentrations and different 
stages of maturity, [Table-1]. The longest vase life attained at $7 \%$ (w/v) sucrose which gave 17.2 days, followed by 15 days for $\mathrm{AgNO}_{3}$ at 30ppm and 7 days for control compared to other concentrations of sucrose and $\mathrm{AgNO}_{3}$ [Table-1]. Carbohydrates are most important compounds in reserve solutions, manly sucrose which sometimes, lonely present in phloem sap. Cut flowers senescence is initiated when energy required for synthesis reactions is considerably reduced. Therefore exogenous application of sucrose would be helpful in delaying senescence by maintaining the structure and activity of mitochondria [23]. Also sucrose act as food source or respiratory substrate and delays the degradation of proteins and improves the water balance of cut flowers [24]. While, Steinitz [25] opined that addition of sucrose to the solution increased the mechanical rigidity of the stem by inducing cell wall thickening and lignifications of vascular tissues. Also $\mathrm{AgNO}_{3}$ is an effective inhibitor of ethylene biosynthesis [26] and act as bactericides [27]. Our results in confirm the results obtained by other researchers [28] and [29] they opined that $\mathrm{AgNO}_{3}$ prevented microbial occlusion of xylem vessels in Dendrobium, thereby enhancing water uptake and increasing longevity of flowers. Awad, et al [30] also attributed the beneficial effect of $\mathrm{AgNO}_{3}$ in the vase water to the production of $\mathrm{Ag}^{+}$ions, which might inhibit the rise of ethylene precursor thereby enhancing longevity of cut flowers.

Table 1- Effect of $\mathrm{AgNO}_{3}$ and sucrose on vase life of Taif rose cut flowers

\begin{tabular}{|c|c|c|c|c|c|c|c|c|c|}
\hline \multirow{3}{*}{ Treatments } & \multicolumn{9}{|c|}{ Vase life after different Pulsing time / hours } \\
\hline & \multicolumn{3}{|c|}{ B } & \multicolumn{3}{|c|}{ H.O } & \multicolumn{3}{|c|}{ C.O } \\
\hline & $5 \mathrm{~h}$ & $10 \mathrm{~h}$ & $24 \mathrm{~h}$ & $5 \mathrm{~h}$ & $10 \mathrm{~h}$ & 24h & $5 \mathrm{~h}$ & $10 \mathrm{~h}$ & $24 \mathrm{~h}$ \\
\hline $\mathrm{AgNO}_{3} 30 \mathrm{ppm}$ & 11.8 & 14.5 & 13.8 & 11 & 13 & 15 & 8.8 & 12.4 & 12.8 \\
\hline $\mathrm{AgNO}_{3} 50 \mathrm{ppm}$ & 11.8 & 14.5 & 12.8 & 10.2 & 13.4 & 13.8 & 9 & 12 & 13.1 \\
\hline $\mathrm{AgNO}_{3} 70 \mathrm{ppm}$ & 10.8 & 11.6 & 12.2 & 10.8 & 13.2 & 13.2 & 7.6 & 9.6 & 11.8 \\
\hline Sucrose $3 \%$ & 9.4 & 11.6 & 12.6 & 13.2 & 14 & 13.8 & 11.6 & 13.4 & 13 \\
\hline Sucrose $5 \%$ & 10.2 & $11 p$ & $11 p$ & 13.8 & 13 & 14.2 & 12.2 & 14.6 & 15.8 \\
\hline Sucrose $7 \%$ & 12.4 & 12 & 13.2 & 13.2 & 14.3 & 17.2 & 14.5 & 13.8 & 13 \\
\hline Control & & $4^{*}$ & & & $7^{*}$ & & & $6^{*}$ & \\
\hline
\end{tabular}

\section{Stages of Maturity}

Depending on results of [Table-1], the (H.O.S) stage result in the highest longevity compared to different stages, these data are consistent with the hypothesis that, smaller buds of cut flowers may abort for lack of carbohydrate [31], similar results obtained by van Meetern, et al [32] in lilies cut flowers, thereby the lack of carbohydrate has been shown to lead to increased ethylene biosynthesis and bud abortion [33], which are consistent with this suggestion. Curiously, supplying added carbohydrate did not consistently reduce ethylene production in very yang buds. They may have insufficient sink strength to compete with expending buds for carbohydrate provide from the vase solution [Table-1], thereby short vase life in flowers had been cut in bud stages compared to other stages [Table-1], may be due to leaching of carbohydrate as reported by Vander Muisers, et al [34] in Asiatic lily, while the flowers cut in complete opening stage import more carbohydrates from the leaves and stem than that taken in H.O.S [19], which in agreement of the results of [Table-1].

\section{Pulsing Time}

The results of [Table-1] showed that the $24 \mathrm{~h}$ pulsing time in preservative solution attained good results compared to other pulsing times, which in agreement of the recommendation of Halevy and Kofranek [35] when he pulsed Lisianthus flower in 6\% sucrose for $24 \mathrm{~h}$ the postharvest life had been improved and flower opening considerably increased [36].

\section{The Combination Effects of $\mathrm{AgNO}_{3}$ and Sucrose on Vase Life and Postharvest Quality of Taif Rose Cut Flowers}

Vase Life- Sucrose or $\mathrm{AgNO}_{3}$ alone was less effective as compared to their combinations with regard to vase life. When $7 \%$ sucrose was added to $30 \mathrm{ppm} \mathrm{AgNO}_{3}$ the vase life was extended to 17.8, 19.1 and 13.9 days for (B), (H.O) and (C.O) stages respectively compared to $9.9,10.5$ and 8.9 days without sucrose for the same mentioned stages, [Table-2], through $24 \mathrm{~h}$ depending on results of [Table-1]. This may be due to the nutrient effect of sucrose [37] and antibacterial effect of $\mathrm{AgNO}_{3}$ [38]. Further more when added $\mathrm{AgNO}_{3}$ to sucrose may suppress autocatalytic ethylene production by inhibiting ethylene action [39], so that the two compound prevent the xylem blockage witch lead to promote water uptake by stem and finally result in a good vase life, similar results by Ohkawa, et al [38].

Table 2- Effect of the best treatment of $\mathrm{AgNO}_{3}$ and sucrose on vase life and postharvest quality of Taif rose cut flowers

\begin{tabular}{lccc|}
\hline & Vase life after different Pulsing time / hours \\
Treatments & B & H.O & C.O \\
\hline $\mathrm{AgNO}_{3} 30 \mathrm{ppm}$ & $13 \mathrm{gf}$ & $15 \mathrm{~d}$ & $12 \mathrm{~h}$ \\
$\mathrm{Sucrose}_{7} \%$ & $13 \mathrm{gf}$ & $17 \mathrm{~b}$ & $14 \mathrm{e}$ \\
$\mathrm{AgNO}_{3} 30 \mathrm{ppm} 7 \%$ sucrose & $17.8 \mathrm{bc}$ & $19.1 \mathrm{a}$ & $13.9 \mathrm{f}$ \\
$\mathrm{Control}^{-}$ & $4 \mathrm{k}$ & $7 \mathrm{j}$ & $6 \mathrm{ji}$ \\
\hline
\end{tabular}

*Different letters explain the significant differences between means, according to Duncan multiple range $p=5.05$.

\section{Chlorophyll Content}

The previous treatments lead to a considerable delay in degradation of $\mathrm{Chl} a$ and $\mathrm{Chl} b$ compared to control [Table-3], [Table-4] and [Table-5]. The concentration of chlorophyll a was higher than chlorophyll $b$ at any point of time throughout the vase life. [Table-3], [Table-4] and [Table-5].

Table 3- Effect of $\mathrm{AgNO}_{3}$ with or without sucrose and sucrose compared to control on chlorophyll content for Taif rose cut flowers in bud stage. (unit was $\mathrm{mgl}^{-1}$ fresh weight).

\begin{tabular}{|c|c|c|c|c|c|c|}
\hline \multirow{3}{*}{ Treatments } & \multicolumn{6}{|c|}{ Days of determinations of chl. $\boldsymbol{a}$ and chl. $\boldsymbol{b}$} \\
\hline & \multicolumn{2}{|c|}{$1^{\text {st }}$ day } & \multicolumn{2}{|c|}{$6^{\text {th }}$ day } & \multicolumn{2}{|c|}{$10^{\text {th }}$ day } \\
\hline & Chl. a & Chl. $b$ & Chl. a & Chl. b & Chl. a & Chl. $b$ \\
\hline $\mathrm{AgNO}_{3} 30 \mathrm{ppm}$ & 0.66 & 0.19 & 0.86 & 0.20 & 0.17 & 0.05 \\
\hline $\mathrm{AgNO}_{3} 30 \mathrm{ppm}+$ sucrose $7 \%$ & 0.93 & 0.21 & 0.79 & 0.17 & 0.20 & 0.04 \\
\hline Sucrose $7 \%$ & 0.97 & 0.29 & 0.64 & 0.18 & 0.15 & 0.04 \\
\hline Control & 0.13 & 0.06 & 0.54 & 0.14 & 0.48 & 0.28 \\
\hline
\end{tabular}

Table 4- Effect of $\mathrm{AgNO}_{3}$ with or without sucrose and sucrose compared to control on chlorophyll content for Taif rose cut flowers in half opening stage. (unit was $\mathrm{mgl}^{-1}$ fresh weight).

\begin{tabular}{|c|c|c|c|c|c|c|}
\hline \multirow{3}{*}{ Treatments } & \multicolumn{6}{|c|}{ Days of determinations of chl. $\mathbf{a}$ and $\mathrm{chl} . \boldsymbol{b}$} \\
\hline & \multicolumn{2}{|c|}{$1^{\text {st }}$ day } & \multicolumn{2}{|c|}{$6^{\text {th }}$ day } & \multicolumn{2}{|c|}{$10^{\text {th }}$ day } \\
\hline & Chl. a & Chl. b & Chl. a & Chl. $b$ & Chl. a & Chl. b \\
\hline $\mathrm{AgNO}_{3} 30 \mathrm{ppm}$ & 0.79 & 0.29 & 0.25 & 0.03 & 0.24 & 0.03 \\
\hline $\mathrm{AgNO}_{3} 30 \mathrm{ppm}+$ sucrose $7 \%$ & 1.34 & 0.46 & 0.75 & 0.14 & 0.19 & 0.07 \\
\hline Sucrose $7 \%$ & 0.50 & 0.13 & 1.10 & 0.32 & 0.09 & 0.05 \\
\hline Control & 0.65 & 0.19 & 0.15 & 0.03 & 0.09 & 0.02 \\
\hline
\end{tabular}


The data show that there was a positive role for sucrose with or without $\mathrm{AgNO}_{3}$ on preserving the flowers in good condition by inhibiting the chlorophyll retention. Similar results were obtained by Tjosolved, et al [40] and Serek, et al [41], Chatterjee, et al [42], and Singh and Tiwari [26].

Table 5- Effect of $\mathrm{AgNO}_{3}$ with or without sucrose and sucrose compared to control on chlorophyll content for Taif rose cut flowers in complete opening stage. (unit was $\mathrm{mgl}^{-1}$ fresh weight).

\begin{tabular}{|c|c|c|c|c|c|c|}
\hline \multirow{3}{*}{ Treatments } & \multicolumn{6}{|c|}{ Days of determinations of chl. $a$ and chl. $b$} \\
\hline & \multicolumn{2}{|c|}{ 1st day } & \multicolumn{2}{|c|}{$6^{\text {th }}$ day } & \multicolumn{2}{|c|}{$10^{\text {th }}$ day } \\
\hline & Chl. a & Chl. $b$ & Chl. a & Chl. $b$ & Chl. a & Chl. b \\
\hline $\mathrm{AgNO}_{3} 30 \mathrm{ppm}$ & 0.51 & 0.14 & 1.05 & 0.58 & 0.08 & 0.02 \\
\hline $\mathrm{AgNO}_{3} 30 \mathrm{ppm}+$ sucrose $7 \%$ & 0.40 & 0.08 & 1.08 & 0.35 & 0.31 & 0.11 \\
\hline Sucrose $7 \%$ & 0.54 & 0.15 & 0.44 & 0.13 & 0.19 & 0.05 \\
\hline Control & 0.42 & 0.13 & 0.37 & 0.12 & 0.07 & 0.03 \\
\hline
\end{tabular}

${ }^{1} \mathrm{mg}^{1-1}$ fresh weight for different stage.

\section{Carbohydrate Content}

Data of [Table-6], [Table-7], [Table-8] and [Table-9] showed that fructose, glucose and sucrose were the main soluble carbohydrates in petals and stems of Taif cut roses. Fructose was the major component in the petals as well as in stems but, generally, its value was higher than in stems. Sucrose contents in petals and stems were lower than those of glucose. The carbohydrate content significantly increased as a result of using $30 \mathrm{ppm} \mathrm{AgNO}_{3}+7 \%$ sucrose till the $5^{\text {th }}$ day then sharply decreased on the $12^{\text {th }}$ day at which the vase life of control was terminated. While stem contents of the previous sugars increased at the beginning of the experiment, then decreased towards the end of the experiment compared to control [Table-6]. Pulsing for $24 \mathrm{~h}$ may enhanced total starch contents of petals as well as compared to untreated cut rose flowers [43]. These results were coincided with those obtained by Zagory and Reid [44] on many cut flowers, on bird of paradise [45], cut rose flowers, [46], chrysanthemum, [47], freesia, [48] on gladiolus cut flower spikes, [49] and tuberose cut flowers spikes [50].

Table 6- Effect of $\mathrm{AgNO}_{3}$ with or without sucrose and sucrose on carbohydrates content for petals of rose cut flowers in bud stage.

\begin{tabular}{|c|c|c|c|c|c|c|c|c|c|}
\hline \multirow{3}{*}{ Treatments } & \multicolumn{9}{|c|}{ Days of determination of carbohydrate contents } \\
\hline & \multicolumn{3}{|c|}{ 1st day } & \multicolumn{3}{|c|}{ 5th day } & \multicolumn{3}{|c|}{ 12th day } \\
\hline & G & $\mathbf{F}$ & s & G & $F$ & s & G & $F$ & s \\
\hline $\mathrm{AgNO}_{3} 30 \mathrm{ppm}$ & 8.08 & 9.63 & 1.55 & 7.03 & 8.65 & 1.92 & 4.89 & 5.57 & 0.68 \\
\hline $\mathrm{AgNO}_{3} 30 \mathrm{ppm}+$ sucrose $7 \%$ & 7.39 & 8.04 & 0.65 & 5.01 & 6.78 & 1.77 & 6.84 & 7.39 & 0.55 \\
\hline Sucrose $7 \%$ & 5.08 & 6.08 & 1.81 & 9.57 & 10.38 & 0.81 & 8.88 & 9.25 & 0.37 \\
\hline Control & 9.78 & 10.64 & 0.86 & 9.76 & 11.14 & 1.39 & 6.38 & 9.71 & 3.33 \\
\hline
\end{tabular}

F: Fructose G: Glucose S: Sucrose (in different tables)

Table 7- Effect of $\mathrm{AgNO}_{3}$ with or without sucrose and sucrose on carbohydrate content for stem of rose cut flowers in bud stage.

\begin{tabular}{|c|c|c|c|c|c|c|c|c|c|}
\hline \multirow{3}{*}{ Treatments } & \multicolumn{9}{|c|}{ Days of determination of carbohydrate contents } \\
\hline & \multicolumn{3}{|c|}{ 1st day } & \multicolumn{3}{|c|}{ 5th day } & \multicolumn{3}{|c|}{ 12th day } \\
\hline & G & $\mathbf{F}$ & s & G & $\mathbf{F}$ & s & G & $\mathbf{F}$ & s \\
\hline $\mathrm{AgNO}_{3} 30 \mathrm{ppm}$ & 4.55 & 6.55 & 2.01 & 3.86 & 3.99 & 0.13 & 5.08 & 6.88 & 1.81 \\
\hline $\mathrm{AgNO}_{3} 30 \mathrm{ppm}+$ sucrose $7 \%$ & 6.58 & 7.23 & 0.66 & 7.27 & 7.46 & 0.19 & 5.52 & 6.11 & 0.59 \\
\hline Sucrose $7 \%$ & 5.18 & 6.89 & 1.71 & 3.07 & 3.26 & 0.19 & 3.48 & 4.09 & 0.61 \\
\hline Control & 5.05 & 5.65 & 0.61 & 6.28 & 7.92 & 1.64 & 5.68 & 6.05 & 0.38 \\
\hline
\end{tabular}

Table 8- Effect of $\mathrm{AgNO}_{3}$ with or without sucrose and sucrose on carbohydrates content for petals of rose cut flowers in half opening stage.

\begin{tabular}{lcccccccccc} 
& \multicolumn{4}{c}{$\begin{array}{c}\text { Days of determination of carbohydrate contents } \\
\text { Treatments }\end{array}$} & \multicolumn{3}{c}{ 1st day } & & \multicolumn{5}{c}{ 5th day } & & \multicolumn{3}{c}{ 12th day } \\
& $\mathbf{G}$ & $\mathbf{F}$ & $\mathbf{S}$ & $\mathbf{G}$ & $\mathbf{F}$ & $\mathbf{S}$ & $\mathbf{G}$ & $\mathbf{F}$ & $\mathbf{S}$ \\
$\mathrm{AgNO}_{3} 30 \mathrm{ppm}$ & 3.55 & 5.55 & 2.01 & 3.86 & 2.99 & 0.13 & 4.08 & 6.88 & 1.81 \\
$\mathrm{AgNO}_{3} 30 \mathrm{ppm}+$ sucrose & $7 \%$ & 5.84 & 7.23 & 0.66 & 7.83 & 8.17 & 0.36 & 8.34 & 10.54 & 2.21 \\
Sucrose $7 \%$ & 4.88 & 5.89 & 1.71 & 10.95 & 12.07 & 1.12 & 2.68 & 4.09 & 0.61 \\
Control & 5.05 & 5.65 & 0.61 & 7.79 & 8.62 & 0.83 & 9.81 & 12.21 & 2.41 \\
\hline
\end{tabular}

Table 9- Effect of $\mathrm{AgNO}_{3}$ with or without sucrose and sucrose on carbohydrate content for stem of rose cut flowers in half opening stage.

\begin{tabular}{|c|c|c|c|c|c|c|c|c|c|}
\hline \multirow{3}{*}{ Treatments } & \multicolumn{9}{|c|}{ Days of determination of carbohydrate contents } \\
\hline & \multicolumn{3}{|c|}{ 1st day } & \multicolumn{3}{|c|}{ 5th day } & \multicolumn{3}{|c|}{ 12th day } \\
\hline & G & $\mathbf{F}$ & S & G & $\mathbf{F}$ & S & G & $\mathbf{F}$ & s \\
\hline $\mathrm{AgNO}_{3} 30 \mathrm{ppm}$ & 4.11 & 5.32 & 1.21 & 5.67 & 6.52 & 0.85 & 3.81 & 4.84 & 1.03 \\
\hline $\mathrm{AgNO}_{3} 30 \mathrm{ppm}+$ sucrose $7 \%$ & 4.99 & 6.23 & 1.29 & 4.69 & 5.92 & 1.23 & 6.07 & 7.49 & 1.42 \\
\hline Sucrose $7 \%$ & 7.43 & 9.78 & 2.35 & 4.69 & 4.92 & 1.23 & 10.46 & 11.07 & 0.61 \\
\hline Control & 5.95 & 6.45 & 0.51 & 7.79 & 8.62 & 0.83 & 9.81 & 12.21 & 2.41 \\
\hline
\end{tabular}

Table 10- Effect of $\mathrm{AgNO}_{3}$ with or without sucrose and sucrose on carbohydrates content for petals of rose cut flowers in complete opening stage.

\begin{tabular}{lcccccccccc} 
Treatments & \multicolumn{3}{c}{$\begin{array}{c}\text { Days of determination of carbohydrate contents } \\
\text { 1st day }\end{array}$} & \multicolumn{4}{c}{ 5th day } & & \multicolumn{3}{c}{ 12th day } \\
& $\mathbf{G}$ & $\mathbf{F}$ & $\mathbf{S}$ & $\mathbf{G}$ & $\mathbf{F}$ & $\mathbf{S}$ & $\mathbf{G}$ & $\mathbf{F}$ & $\mathbf{S}$ \\
$\mathrm{AgNO}_{3} 30 \mathrm{ppm}$ & 5.43 & 7.68 & 2.25 & 4.69 & 5.92 & 1.23 & 7.09 & 7.81 & 0.72 \\
$\mathrm{AgNO}_{3} 30 \mathrm{ppm}+$ sucrose & $7 \%$ & 5.98 & 6.28 & 031 & 8.86 & 9.11 & 0.25 & 7.39 & 10.51 & 3.12 \\
Sucrose 7\% & 5.95 & 6.87 & 0.92 & 8.83 & 9.45 & 0.62 & 9.38 & 9.99 & 0.61 \\
Control & 3.86 & 4.17 & 0.31 & 9.45 & 10.06 & 0.61 & 9.91 & 11.55 & 1.64 \\
\hline
\end{tabular}

Table 11- Effect of $\mathrm{AgNO}_{3}$ with or without sucrose and sucrose on carbohydrate content for stem of rose cut flowers in complete opening stage.

\begin{tabular}{|c|c|c|c|c|c|c|c|c|c|}
\hline \multirow{3}{*}{ Treatments } & \multicolumn{9}{|c|}{ Days of determination of carbohydrate contents } \\
\hline & \multicolumn{3}{|c|}{ 1st day } & \multicolumn{3}{|c|}{ 5th day } & \multicolumn{3}{|c|}{ 12th day } \\
\hline & G & $\mathbf{F}$ & s & G & $\mathbf{F}$ & S & G & $\mathbf{F}$ & $\mathbf{s}$ \\
\hline $\mathrm{AgNO}_{3} 30 \mathrm{ppm}$ & 6.46 & 7.73 & 1.27 & 4.86 & 5.83 & 0.97 & 4.93 & 5.82 & 0.89 \\
\hline $\mathrm{AgNO}_{3} 30 \mathrm{ppm}+$ sucrose $7 \%$ & 7.14 & 8.63 & 1.49 & 5.95 & 6.68 & 0.75 & 6.39 & 9.5 & 2.12 \\
\hline Sucrose $7 \%$ & 4.65 & 5.97 & 1.32 & 6.04 & 7.67 & 1.63 & 4.67 & 5.92 & 1.25 \\
\hline Control & 6.05 & 6.96 & 0.91 & 9.45 & 10.06 & 0.61 & 9.91 & 11.55 & 1.64 \\
\hline
\end{tabular}

\section{Conclusion}

A significant improvement in vase life of Taif rose cut flowers was occurred when treated with $30 \mathrm{ppm} \mathrm{AgNO}_{3}$ and the effect was further improved when $\mathrm{AgNO}_{3}$ at $30 \mathrm{ppm}$ combined with $7 \%(\mathrm{w} / \mathrm{v})$ sucrose which attained the best result compared to other concentrations of sucrose. Also chlorophyll and carbohydrate had been retarded during the postharvest life as the result of using this combination treatment which they represent one of the more important parameters of good performance of postharvest physiology of cut flowers.

\section{Conflicts of Interest: None Declared.}




\section{References}

[1] AIPH (2003) International Statistics Flowers and Plants Union Fleurs, Den Haag.

[2] Nukui H., Kudo S., Yamashita A. \& Satoh S. (2004) Journal of Experimental Botany, 55(397), 641-650.

[3] Bazaid S.A. (2004) Journal of the Egyptian Academy for Development, 5(1), 77-90.

[4] He S., Joyce D.C., Irving D.E., Faragher J.D. (2006) Postharvest Biol. Technol., 41, 78-84.

[5] Da Silva J.A.T. (2003) Online J. Biol. Sci., 3, 406-442.

[6] Halevy A.H., Mayak S. (1981) Acta Horticulture, 3, 59-143.

[7] Marandi R.A., Hassani A., Abollahi A. and Hanafi S. (2011) J. Med. Plant. Res., 5(20), 5039-5043.

[8] Hassan F. (2005) International Journal of Horticultural Science, 10(4), 101-107.

[9] Kazemi M., Hadvi E. and Hekmati J. (2010) World Applied Sci. J., 10, 737-740.

[10]An J., Zhang M., Wang S. \& Tang J. (2008) LWT-Food Science and Technology, 41(6), 1100-1107.

[11]Kazemi M., Hadvi E. and Hekmati J. (2011) Am. J. Plant Physiol., 6, 106-112.

[12]Kofranek A.M. and Paul J.L. (1975) Acta. Hort., 41, 199-206.

[13]Elgimabi M.N.E. (2011) Am. J. Agric. Biol. Sci., 6(1), 128-133.

[14]Reddy T., Nagarajaiah C. and Raju B. (1988) Hort. Absts., 59, 2360.

[15]Asrar A.W.A. (2012) J. Saudi Soc. Agric. Sci., 11, 29-35.

[16]Delaporte K., Klieber A. and Sedgley M. (2005) Journal of Horticultural Science and Biotechnology, 80(4), 471-475.

[17]Pun U.K., Shimizu H., Tanase K. and Ichimura K. (2005) Acta Hort., 669, 171-174.

[18]Butt S.J. (2005) International Journal of Agricultural and Biology, 7(1), 91-99.

[19]Pun U.K., Ichimura K. (2003) Japan Agricultural Research Quarterly, 37(4), 219-224.

[20]Abou El-Ghait E.M., Gomaa A.O., Youssef A.S.M. \& Mohamed Y.F. (2012) Research Journal of Agriculture \& Biological Sciences, 8(2), 261-271.

[21]Butt S.J. (2003) A Review on prolonging the vase life of rose cut flowers, Pakistan Rose Annual, Pakistan National Rose Society, 49-53.

[22]Nair S.A., Singh V. and Sharma T.V. (2003) Jour. Tropic. Agric., 41, 56-58.

[23]Coort G.D. (1973) Hort. Science, 8, 195-198.

[24]Sujatha A., Singh V. and Sharma T.V.R.S. (2003) J. Tropical Agri., 41, 56-58.

[25]Steinitz B. (1982) Gartenbouwissenschaft, 47, 77-81.

[26]Singh A.K. and Tiwari A.K. (2002) South Indian Horticulture, 50 (1/6), 140-144.

[27]Han S.S. (1998) HortScience, 33, 731-733.

[28]Ketsa S., Piyasaengthong Y., Prathuangwong S. (1995) Postharvest Biology and Technology, 5, 109-117.

[29]Loubaud M. \& van Doorn W.G. (2004) Postharvest Biology and Technology, 32(3), 281-288.
[30]Awad A.R.E., Meawad A., Dawh A.K. and El-saka M. (1986) J. Ornamental Hort., 181, 177-193.

[31]Spikman G. (1989) Scientia Horticulturae, 39(1), 73-81.

[32]Meeteren U.V. \& Proft M. (1982) Physiologia Plantarum, 56(3), 236-240.

[33]Woltering E.J. and Van Doom W.G. (1988) Journal of Experimental Botany, 39(11), 1605-1616.

[34]van der Meulen- Muisers J.J.M., van Oeveren J.C., van der Plas L.H.W., van Tuyl J.M. (2001) Postharvest Biology and Technology, 21, 201-211.

[35]Halevy A.H. and Kofranek A.M. (1984) HortScience, 19, 845847.

[36]Deplarote K.L. and Sedgley M. (2004) Acta Horticulturae, 630, 77-84.

[37]Delaporte K.L., Klieber A. \& Sedgley M. (2000) Postharvest Biology and Technology, 19(2), 181-186.

[38]Ohkawa K., Kusuhara Y. \& Suh J.N. (1999) HortScience, 34, 112-113.

[39]Ichimura K. and Hiraga T. (1998) J. Jpn. Soc. Hort. Sci., 68.

[40]Tjosvold S.A., Wu M.S. (1994) HortScience, 29(4), 293-294.

[41]Serek M., Sisler E., Reid M. (1994) Journal of American for Horticultural Science, 119(6), 1230-1233.

[42]Chatterjee S.R., Bhattacharjee S.K. and Wangi M.M. (2003) Ind. J. Hort., 60, 394-398.

[43]Mayak S., Bravdo B., Gvilli A. and Halevy A.H. (1973) Scientia Horticulturae, 1, 357-365.

[44]Zagory D. and Reid M.S. (1986) J. Am. Soc. Hort. Sci., 111, 154-158.

[45]El-Saka M.M. (1992) Physiological studies for increasing the longevity of some cut flowers, Ph. D. Thesis, Faculty of Agric., Zagazig University, Egypt.

[46]Anju B., Tripathi S.N., Sehgal O.P., Bhat A. (1999) Advances in Horticulture and Forestry, 6, 125-131.

[47]Kwon H., Kim K. (2000) Journal of the Korean Society for Horticultural Sciences, 41(2), 135-138.

[48]Gendy A.S. (2000) Physiological study on the effects of some postharvest treatments on gladiolus cut flowers, M. Sc. Thesis, Faculty of Agric., Zagazig University, Egypt.

[49]El-Bouhy N.F. (2002) Effect of some postharvest treatments on polyanthus tuberose cut flowers, M.Sc. Thesis, Faculty of Agric., Zagazig University, Egypt.

[50]Mohammad Y.F. (2009) The effect of certain agricultural postharvest treatments on some ornamental plants, M.Sc. Thesis, Faculty of Agriculture., Moshtohor, Benha University, Egypt.

[51]El-Bouhy N.F. (2010) Physiological studies on the effect of some postharvest treatments on some cut flowers, Ph.D. The sis, Faculty of Agric., Zagazig University, Egypt.

[52]Gendy A.S. and Hamad E.H. (2011) J. Product. and Dev., 16 (3), 397-414.

[53]van Doorn W.G. (1997) Water relations of cut flowers, Horticultural Reviews, 18. 